\title{
Drought assessment in Iraq using analysis of Standardized precipitation index (SPI)
}

\author{
Yaseen K. AL-Timimi, Monim H. AL-Jiboori \\ Department of Atmospheric Sciences, College of Science, Al-Mustansiriyah University
}

E-mail: yaseen_altimimi@yahoo.com

\begin{abstract}
The Present study investigated the drought in Iraq, by using the rainfall data which obtained from 39 meteorological stations for the past 30 years (1980-2010). The drought coefficient calculated on basis of the standard precipitation index (SPI) and then characteristics of drought magnitude, duration and intensity were analyzed. The correlation and regression between magnitude and duration of drought were obtained according the (SPI) index. The result shows that drought magnitude values were greater in the northeast region of Iraq.
\end{abstract}

Key words

Iraq,

Meteorological drought, Standardized precipitation index (SPI).
Article info.

Received: Seb. 2013

Accepted: Feb. 2014

Published: Apr. 2014

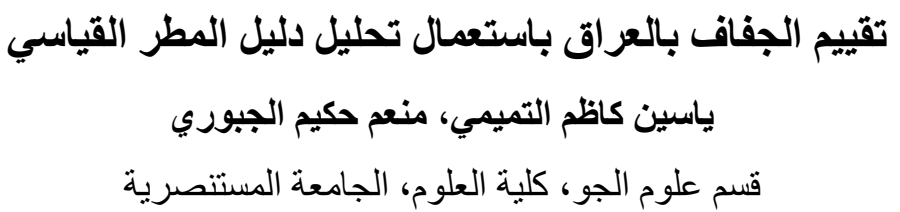

تتناول الدر اسة الحالية الجفاف في العر اق، حيث تم دراسة ظاهرة الجفاف من خلال جمع بيانات الامطار الثهرية والتي

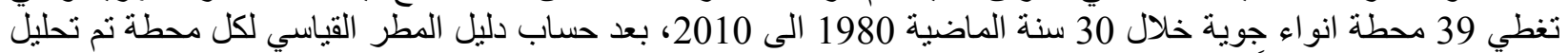

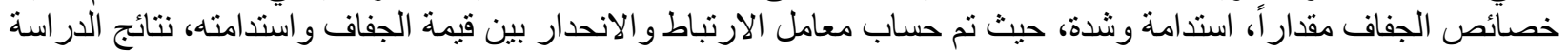
توضح بان اكبر مقدار من الجفاف كان في المنطقة الثمالية الثرقية من العراق.

\section{Introduction}

Drought is an insidious natural hazard that is generally perceived to be a prolonged period with significantly lower precipitations relative to normal levels [1]. The reasons for the occurrence of droughts are complex because they depend not only on atmosphere, but also on the hydrologic processes [2]. Further, drought was ranked first followed by tropical cyclones, regional floods, earthquakes, and volcanoes based on most of the hazard characteristics and impacts [3].
Droughts are extreme hydrological events which may adversely affect social, economic, cultural, political and other functions of a region during dry periods [4]. There are several indices that measure to what extent precipitation for a given period has deviated from historically established norms. Although none of the major indices is inherently superior to the rest in all circumstances, some indices are better suited than others for certain uses [4]. In order to understand that a deficit of precipitation has 
different impacts on the groundwater, reservoir storage, soil moisture, snow cover, and streamflow [4]. McKee et al. [5] developed the standardized precipitation index (SPI); it was designed to quantify the precipitation deficit for multiple time scales. These time scales reflect the impact of drought on the availability of the different water resources. Soil moisture conditions respond to precipitation anomalies on a relatively short time scale, while groundwater, streamflow, and reservoir storage reflect the longer-term precipitation anomalies[5]. McKee et al. used a classification system which is based on the water and dry climates and can be represented in the same way by means of SPI. In addition, wet periods can also be monitored using the SPI McKee et al., [6]. McKee also defined the criteria for a "drought event" for any time scale. A deficit occurs any time that the SPI is continuously negative. The accumulated magnitude of deficits is referred to as drought magnitude, and it is the positive sum of the SPI for all the months within a drought event.

The main purpose of this study is to identify various drought properties on the basis of SPI analysis for 39 stations in Iraq. Empirical relationships are provided through scatter diagrams between the drought magnitude and duration during the period from 1980 to 2010.

\section{Study Area}

Iraq is located in the south - west of Asia, to the north - east of the Arab homeland, bounded on the north by Turkey, on the east by Iran, on the west by Syria, Jordan and Saudi Arabia, on the South by Arab Gulf, Kuwait and Suadi Arabia. Iraq lies between latitudes $29^{\circ} 5^{\prime}$ and $37^{\circ} 22^{\prime}$ north and between longitudes $38^{\circ} 45^{\prime}$ and $48^{\circ} 45^{\prime}$ east. The area of Iraq covers 435052 Sq.Km [7].

\section{Methodology}

\section{Rainfall data collection and analysis}

The monthly rainfall data of 39 meteorological stations for the time period $19 \wedge 0-2010$ were acquired from the Iraqi Meteorological Organization and Seismology (ministry of transportation) and Ministry of Agriculture and Water Resources (Kurdistan Region), which covered Iraq from the north to the south as shown in Fig.1. The identification and assessment of drought severity were done using the SPI. The SPI is calculated from the monthly precipitation record. The empirical calculations of drought descriptions such as moderate, severe and extreme drought cases are calculated and accordingly the classifications are done quickly at a single site and correspond to SPI categories as shown in Table 1.

\section{The standard precipitation index (SPI).}

SPI is calculated by fitting gamma distribution function to given frequency distribution of precipitation totals for a given station, and then transforming the gamma distribution to a normal distribution with mean zero and variance of one. The steps and equations to calculate SPI are as follows [7]:

The precipitation data are calculated using the gamma probability density function which is defined as [8];

$g(x)=\frac{1}{\beta^{\alpha} \Gamma(\alpha)} x^{\alpha-1} e^{-x / \beta} \quad$ for $x>0$

where $\quad \alpha \succ 0$ is the shape parameter, $\beta \succ 0$ is a scale parameter and $x \succ 0$ is the amount of precipitation. $\Gamma(\alpha)$ defines the gamma function. $\alpha$ and $\beta$ are parameters to be estimated for each station for each time step of interest. The maximum likelihood solutions are used to optimally estimate the 
gamma distribution parameters $\alpha$ and $\beta$ :

$\hat{\alpha}=\frac{1}{4 A}\left(1+\sqrt{1+\frac{4 A}{3}}\right)$

$\hat{\beta}=\frac{\bar{x}}{\hat{\alpha}}$

$A=\ln (\bar{x})-\frac{\sum \ln (x)}{n}$

and $\mathrm{n}$ is the number of precipitation observations. This allows the rainfall distribution at the station to be effectively represented by a mathematical cumulative probability function given by[9]:

$G(x)=\int_{0}^{x} g(x) d x=\frac{1}{\hat{\hat{\beta}^{\hat{\alpha}}} \Gamma(\alpha)} \int_{0}^{x} x^{\hat{\alpha}-1} e^{-x / \widehat{\beta}} d x$

Since the gamma function is undefined for $\mathrm{x}=0$ and a precipitation distribution may contain zeros, the cumulative probability becomes:

$H(x)=q+(1-q) G(x)$

where $\mathrm{q}$ is the probability of a zero. The cumulative probability $\mathrm{H}(\mathrm{x})$ is then transformed to the standard normal distribution to yield SPI [6].

The SPI calculated for 3-months over 30 years period and 39 different meteorological stations.SPI was calculated from total rainy season from Dec. to Feb. to describe longterm drought. SPI values of equal or less than -1.0 were used to determine drought intensity according to table 1.the frequency of occurrence of drought was determine by looking at the number of dry station $(\mathrm{SPI}<-$ 1.0) since 1980.

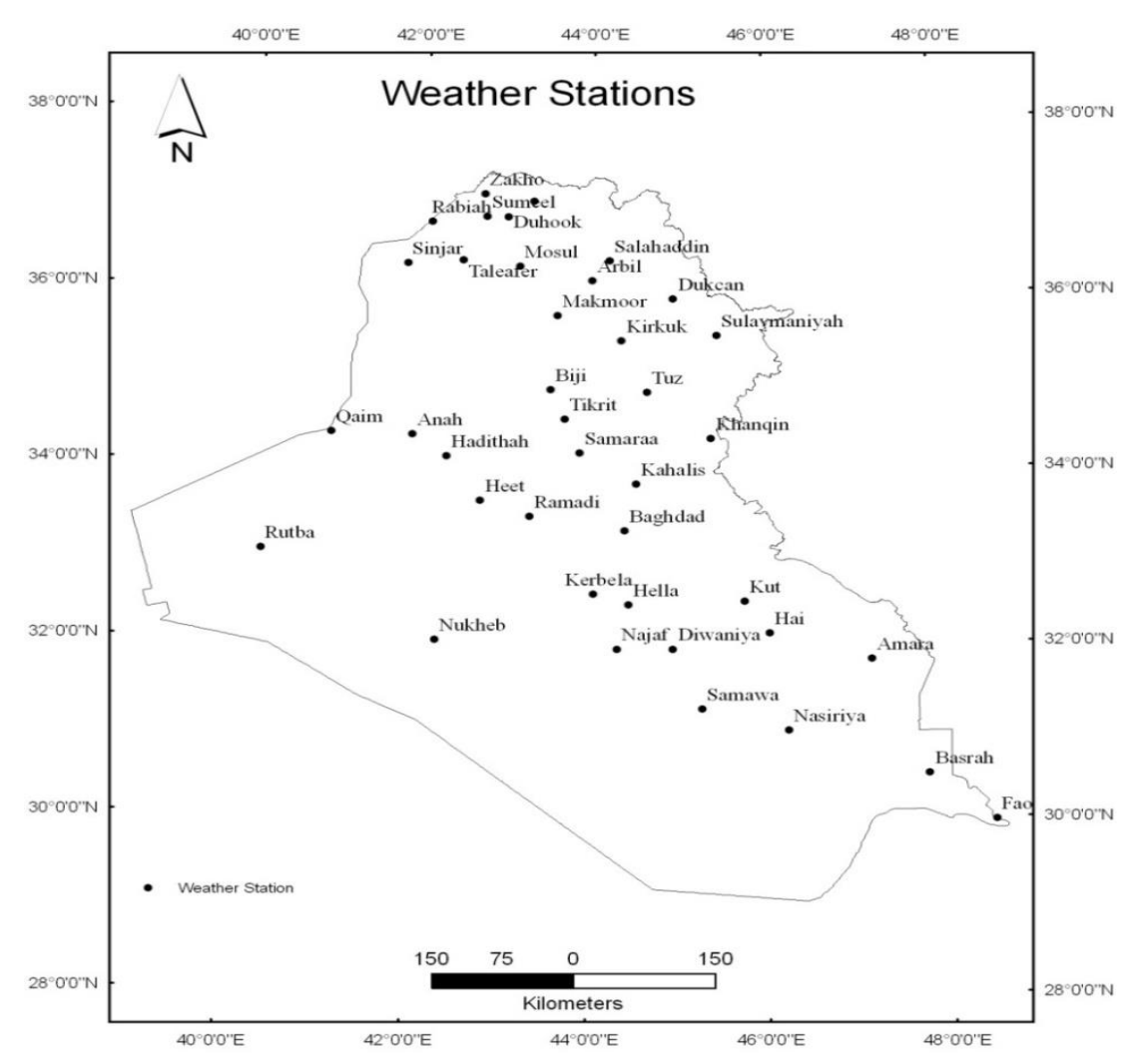

Fig. 1: Meteorological stations in Iraq. 
Table 1: Standard precipitation index categories [5].

\begin{tabular}{|c|c|}
\hline SPI values & Drought Category \\
\hline 0 to -0.99 & Mild drought \\
\hline-1.00 to -1.49 & Moderate drought \\
\hline-1.5 to -1.99 & Severe drought \\
\hline-2 or more & Extreme drought \\
\hline
\end{tabular}

\section{Drought parameters}

Temporal drought characters are determined using SPI analysis. Drought magnitude, $\mathrm{M}_{\mathrm{j}}$, is defined as the average negative deviation from the truncation level $x_{0}$. The drought intensity $I_{j}$ of the $j^{\text {th }}$ dry period is defined as the ratio of drought magnitude to drought duration, $\mathrm{L}_{\mathrm{j}}$.

\section{Results and Discussion}

The SPI values were calculate to observe anomalous dry and wet years over the study period. The 3 month SPI values for six stations in the north selected (Dukcan and Mosul), middle selected (Baghdad and Basrah) and south selected (Rutba and Nukheb ) regions of the study area are shown in Figs.2 and 3. Appearance of drought is happening every time when SPI is negative and it is intensity comes to -1.0 or lower. Drought stops when SPI is positive. The duration of every drought appearance is determined by negative index values. Accumulated totals of negative values of SPI could also be used as a measure of drought severity. The analysis shows that a non-uniform cyclic pattern of drought /wet periods were observed during the period 1980 to 2010 Fig.2. Drought on seasonal basis were observed to exist more often during the historical years, especially at the years 1983, 1998, 1999, 2007, and 2008. The SPI analysis indicate the presence of two drought types regarding the extent of event; local(regional) and national. National drought having full dry extent at all meteorological stations, occur more seldom. National drought events on seasonal basis occurred during the historical years of
1983,1998, 1999, 2000 and 2008. On the other hand, local drought events occurring at one or two regions are more frequent (1990, 2000, 2001, 2004, 2005, 2006 and 2009 are local drought seasons).
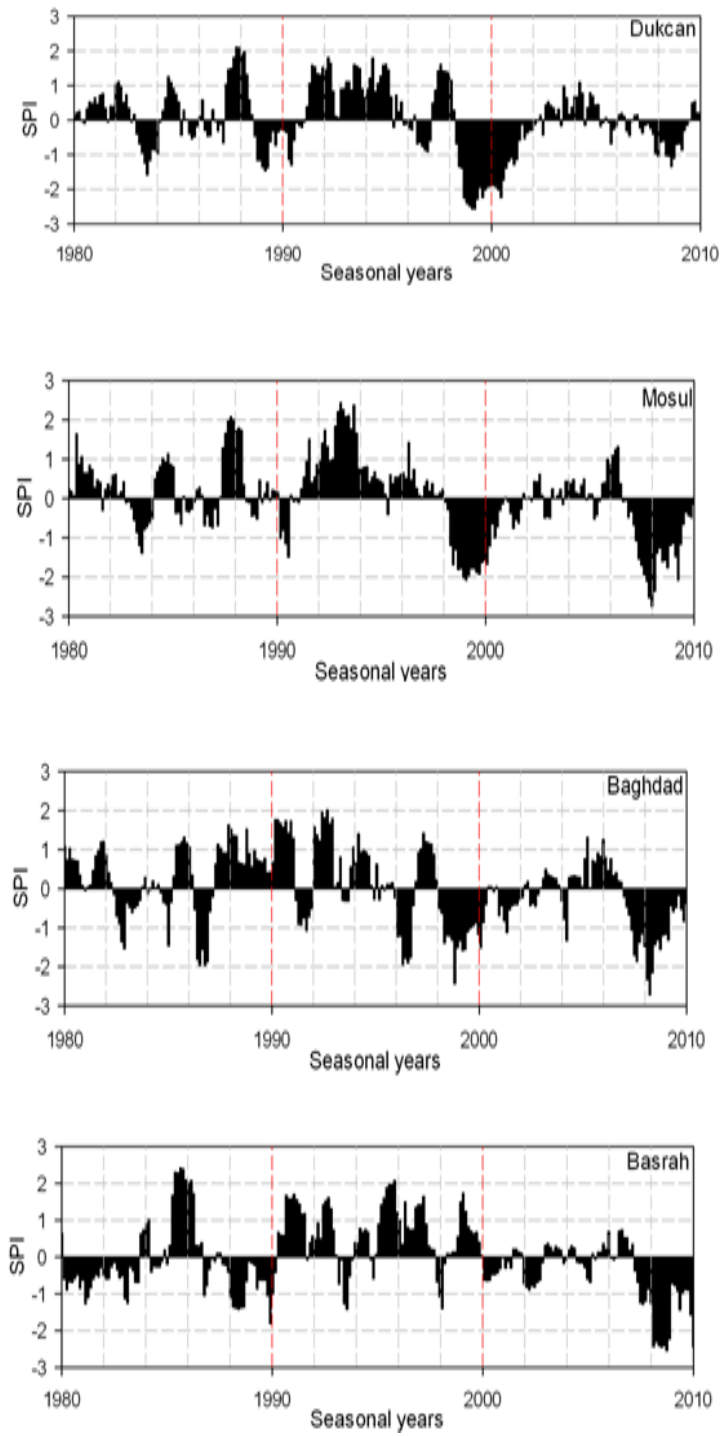

Fig. 2: SPI time series for Dukcan, Mosul, Baghdad and Basrah stations. 

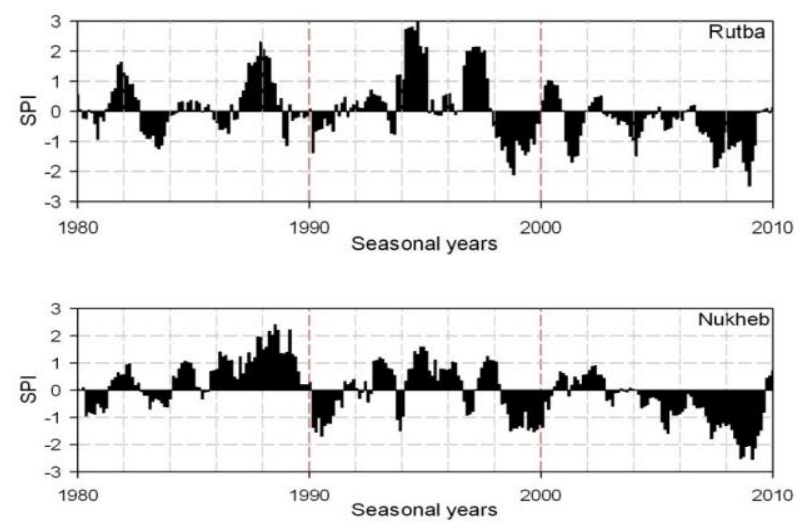

Fig. 3: SPI time series Rutba and Nukheb stations.
Table 2, shows various statistical parameters concerning drought duration, magnitude and intensity based on SPI analysis values at standard truncation levels of zero. These drought features refer to past observations, but their statistical parameters are useful for what-if analysis, conditionally valid also for the future. For instance, one can find drought magnitude, which corresponds to a given drought duration, as shown in Fig. 3.

Table 2: Statistical values of drought magnitude (M), duration (L), and intensity (I).

\begin{tabular}{|c|c|c|c|c|c|c|}
\hline \multirow[b]{2}{*}{$\begin{array}{l}\text { statistical } \\
\text { parameters }\end{array}$} & \multicolumn{3}{|c|}{ Dukan Station } & \multicolumn{3}{|c|}{ Mosul Station } \\
\hline & $\begin{array}{c}\text { Magnitude } \\
\text { M (mm) }\end{array}$ & $\begin{array}{l}\text { duration } \\
\text { L(month) }\end{array}$ & $\begin{array}{l}\text { intensity } \\
\mathrm{I}(\mathrm{mm})\end{array}$ & $\begin{array}{l}\text { Magnitude } \\
\text { M (mm) }\end{array}$ & $\begin{array}{l}\text { duration } \\
\mathrm{L} \text { (month) }\end{array}$ & $\begin{array}{l}\text { intensity } \\
\mathrm{I}(\mathrm{mm})\end{array}$ \\
\hline Max & 17.40 & 8 & 2.18 & 14.59 & 8 & 1.82 \\
\hline Min & 0.04 & 1 & 0.04 & 0.03 & 1 & 0.03 \\
\hline Average & 3.45 & 4.48 & 0.77 & 3.75 & 4.46 & 0.84 \\
\hline \multirow{2}{*}{$\begin{array}{c}\text { statistical } \\
\text { parameters }\end{array}$} & \multicolumn{3}{|c|}{ Baghdad Station } & \multicolumn{3}{|c|}{ Rutba Station } \\
\hline & $\begin{array}{c}\text { Magnitude } \\
\text { M (mm) }\end{array}$ & $\begin{array}{l}\text { duration } \\
\mathrm{L} \text { (month) }\end{array}$ & $\begin{array}{c}\text { intensity } \\
\text { I (mm) }\end{array}$ & $\begin{array}{l}\text { Magnitude } \\
\text { M (mm) }\end{array}$ & $\begin{array}{l}\text { duration } \\
\mathrm{L} \text { (month) }\end{array}$ & $\begin{array}{l}\text { intensity } \\
\text { I (mm) }\end{array}$ \\
\hline Max & 13.95 & 8 & 1.74 & 10.97 & 8 & 1.37 \\
\hline Min & 0.03 & 1 & 0.03 & 0.02 & 1 & 0.02 \\
\hline Average & 3.32 & 3.69 & 0.90 & 3.32 & 4.78 & 0.69 \\
\hline \multirow[b]{2}{*}{$\begin{array}{c}\text { statistical } \\
\text { parameters }\end{array}$} & \multicolumn{3}{|c|}{ Nukheb Station } & \multicolumn{3}{|c|}{ Basrah Station } \\
\hline & $\begin{array}{c}\text { Magnitude } \\
\text { M (mm) }\end{array}$ & $\begin{array}{l}\text { duration } \\
\mathrm{L} \text { (month) }\end{array}$ & $\begin{array}{c}\text { intensity } \\
\text { I (mm) }\end{array}$ & $\begin{array}{l}\text { Magnitude } \\
\text { M (mm) }\end{array}$ & $\begin{array}{l}\text { duration } \\
\mathrm{L} \text { (month) }\end{array}$ & $\begin{array}{l}\text { intensity } \\
\text { I (mm) }\end{array}$ \\
\hline Max & 12.65 & 8 & 1.58 & 15.31 & 8 & 1.91 \\
\hline Min & 0.20 & 1 & 0.2 & 0.07 & 1 & 0.07 \\
\hline Average & 3.76 & 4.56 & 0.82 & 3.58 & 5.08 & 0.70 \\
\hline
\end{tabular}

It is clear from Fig.4 that increases in the drought duration result in increased drought magnitude. Similar graphs can be obtained for other truncation levels. The only expected difference will be in the slopes of the relationships, which are almost equivalent to straight lines that pass almost through the origins. 

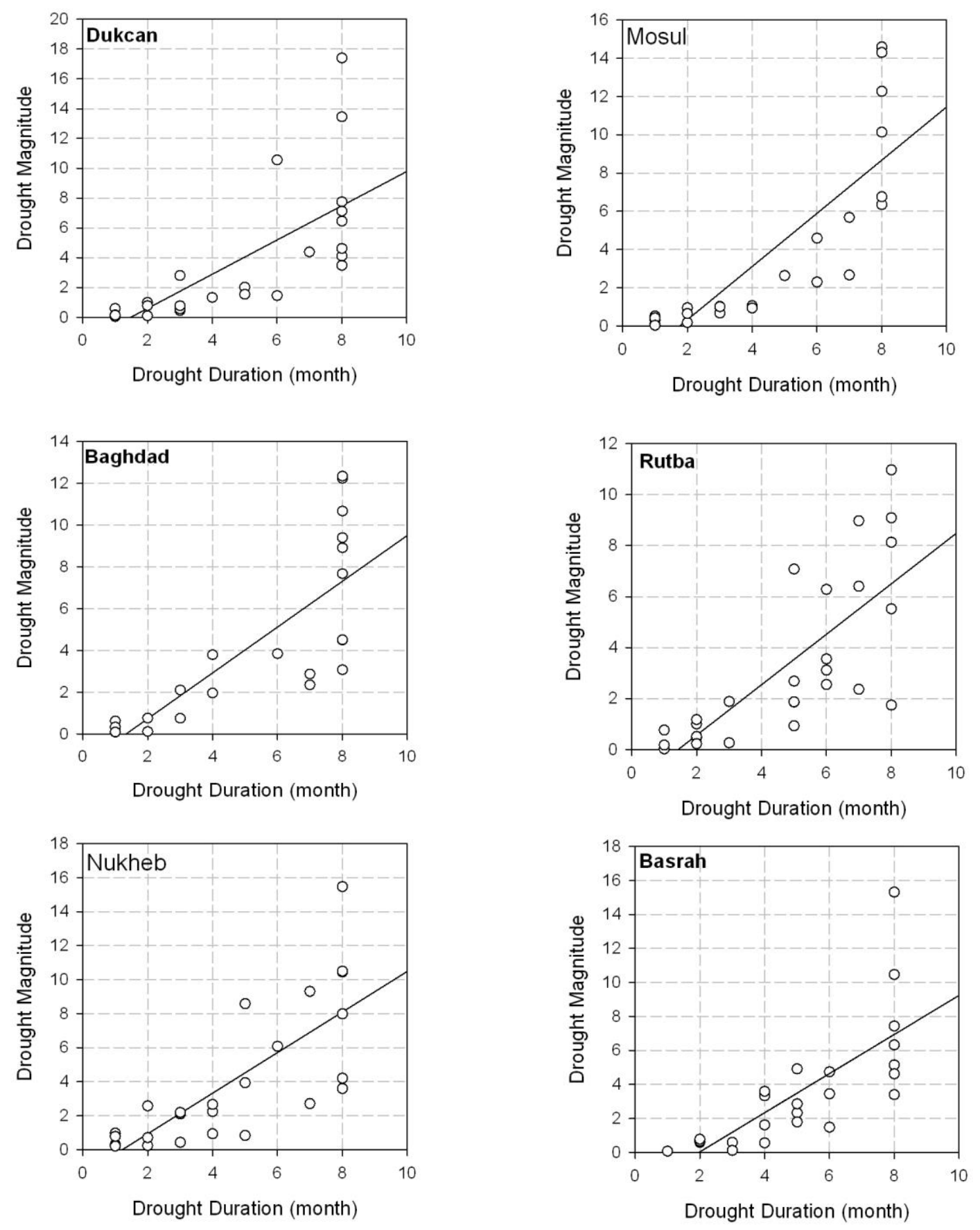

Fig. 4: Scatter diagrams of Magnitude and Duration.

The SPI is used for the identification of various drought characteristics such as the duration, magnitude, and intensity at different standard truncation levels. Basic formulations are given for these drought features and their applications are presented for 39 meteorological stations in Iraq. The relationships between the drought duration and magnitude are provided in the form of scatter diagrams with the best straight-line fits. These are obtained for truncation levels zero. 
Table 3: Statistical values of drought for 39 stations.

\begin{tabular}{|c|c|c|c|c|c|}
\hline Station & $\begin{array}{l}\text { Max } \\
\text { Magnitude }\end{array}$ & $\begin{array}{l}\text { Max } \\
\text { Intensity }\end{array}$ & $\begin{array}{l}\text { correlation } \\
\text { coefficient }\end{array}$ & Regression & $\begin{array}{l}\text { Year of Max } \\
\text { Magnitude }\end{array}$ \\
\hline Duhook & 12.3 & 1.5 & 0.78 & $Y=-1.45+1.09 \mathrm{X}$ & 2008-2009 \\
\hline Kirkuk & 18.4 & 2.3 & 0.77 & $Y=-4.09+1.65 X$ & $2008-2009$ \\
\hline Emadiyah & 18.0 & 2.0 & 0.75 & $Y=-2.21+1.32 X$ & 1999-2000 \\
\hline Khanqin & 16.7 & 2.1 & 0.76 & $Y=-1.82+1.24 X$ & 1999-2000 \\
\hline Makmoor & 15.1 & 1.9 & \begin{tabular}{|l|}
0.87 \\
\end{tabular} & $Y=-2.34+1.38 X$ & 1999-2000 \\
\hline Mosul & 14.6 & 1.8 & 0.83 & $Y=-2.45+1.39 X$ & 1999-2000 \\
\hline Rabiah & 16.5 & 2.1 & 0.76 & $\mathrm{Y}=-3.24+1.38$ & 1999-2000 \\
\hline Salahaddin & 11.8 & 1.5 & 0.9 & $Y=-2.87+1.46 \mathrm{X}$ & $2000-2001$ \\
\hline Sinjar & 14.3 & 1.8 & 0.89 & $Y=-2.78+1.5 X$ & 1999-2000 \\
\hline Sulaymaniyah & 18.1 & 2.3 & 0.75 & $Y=-1.53+1.14 X$ & 1999-2000 \\
\hline Sumeel & 15.6 & 2.0 & 0.81 & $Y=-3.26+1.54 X$ & 1999-2000 \\
\hline Taleafer & 14.8 & 1.8 & 0.83 & $Y=-3.2+1.56 X$ & $1999-2000$ \\
\hline Tuz & 15.0 & 1.9 & 0.77 & $Y=-1.81+1.27 X$ & 2008-2009 \\
\hline Zakho & 13.7 & 1.7 & 0.8 & $Y=-1.79+1.23 X$ & $2007-2008$ \\
\hline Dukcan & 17.4 & 2.2 & 0.73 & $Y=-1.69+1.14 X$ & 1999-2000 \\
\hline Arbil & 17.5 & 2.2 & 0.82 & $Y=-1.52+1.13 X$ & $1999-2000$ \\
\hline Qaim & 12.6 & 1.6 & 0.86 & $Y=-2.05+1.24 X$ & 1999-2000 \\
\hline Basrah & 15.3 & 1.9 & 0.74 & $Y=-2.26+1.15 X$ & $2008-2009$ \\
\hline Fao & 16.0 & 2.0 & 0.67 & $Y=-0.94+0.93 X$ & $2008-2009$ \\
\hline Hai & 11.7 & 1.5 & 0.87 & $Y=-0.85+1.09 X$ & $2008-2009$ \\
\hline Amara & 11.7 & 1.5 & 0.87 & $Y=-1.63+1.16 X$ & 2008-2009 \\
\hline Kut & 12.2 & 1.5 & 0.81 & $Y=-0.79+0.95 X$ & $2008-2009$ \\
\hline Biji & 14.5 & 1.8 & 0.75 & $Y=-1.4+1.14 X$ & $2000-2001$ \\
\hline Tikrit & 13.5 & 1.7 & 0.74 & $Y=-1.24+1.05 X$ & 1998-1999 \\
\hline Samaraa & 13.8 & 1.7 & 0.82 & $Y=-1.72+1.16 X$ & $2007-2008$ \\
\hline Baghdad & 14.0 & 1.7 & 0.78 & $Y=-1.45+1.09 X$ & $2008-2009$ \\
\hline Kahalis & 15.3 & 1.9 & 0.69 & $Y=-1.18+1.24 X$ & 1999-2000 \\
\hline Ramadi & 9.7 & 1.2 & 0.86 & $Y=-0.95+X$ & $2008-2009$ \\
\hline Heet & 9.5 & 1.2 & 0.79 & $Y=-1.03+0.94 X$ & 2008-2009 \\
\hline Hadithah & 13.1 & 1.6 & 0.86 & $Y=-1.58+1.15 X$ & $2007-2008$ \\
\hline Anah & 11.1 & 1.4 & 0.73 & $Y=-0.93+0.95 X$ & 1999-2000 \\
\hline Rutba & 11.0 & 1.4 & 0.76 & $Y=-1.41+0.98 X$ & 1999-2000 \\
\hline Kerbela & 14.3 & 1.8 & 0.67 & $Y=-1.02+1.05 X$ & 1999-2000 \\
\hline Najaf & 8.5 & 1.1 & 0.73 & $Y=-2.46+1.35 X$ & $2008-2009$ \\
\hline Nukheb & 12.7 & 1.6 & 0.76 & $Y=-1.45+1.19 X$ & $2008-2009$ \\
\hline Diwaniya & 14.6 & 1.8 & 0.81 & $Y=-1.82+1.24 X$ & $2008-2009$ \\
\hline Samawa & 10.1 & 1.3 & 0.82 & $Y=-1.45+0.93 X$ & $2008-2009$ \\
\hline Nasiriya & 14.4 & 1.8 & 0.71 & $Y=-1.05+1.02 X$ & $2008-2009$ \\
\hline Hella & 12.2 & 1.5 & 0.88 & $Y=-0.78+1.08 X$ & $2008-2009$ \\
\hline
\end{tabular}


Tables 3 summarize correlation coefficient between magnitude and duration of drought in all stations with range (0.67-0.9). Fig.5 was plotted by using Arc GIS 9.3,it is shows that the stations Kirkuk, Sulaymaniyah, Dukcan and Arbil have a high values of magnitude drought ranged from (18.4 to 17.4) $\mathrm{mm}$ during the seasonal years 19992000 , this mean the northeast region of Iraq faced high drought during the period 19802012.

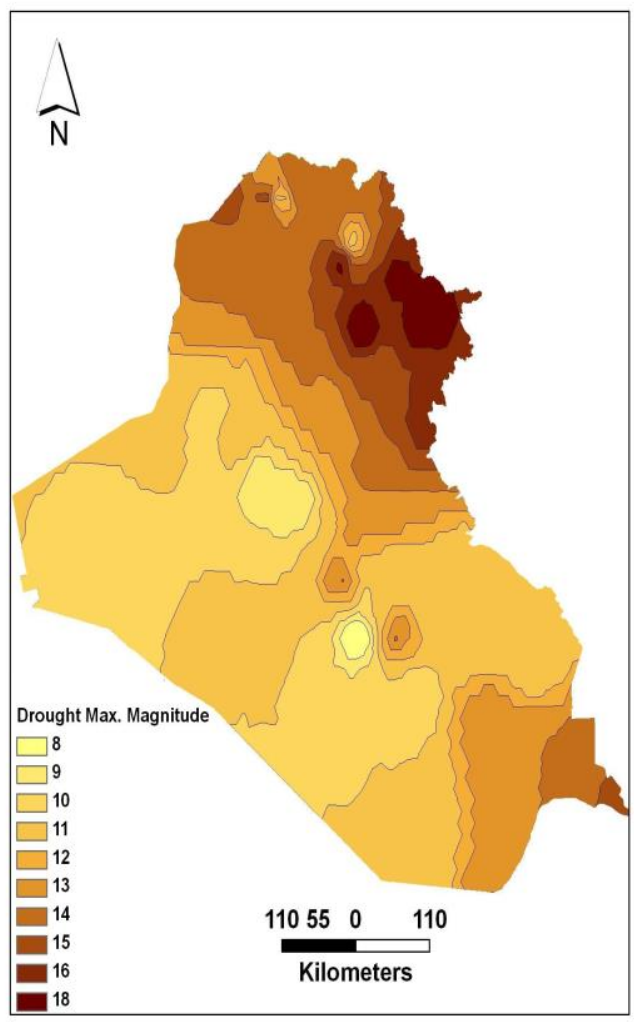

Fig. 5: Map of drought Magnitude for 30 years (1980-2010).

\section{Conclusion}

This study was focused on identification of various drought characteristics, such as magnitude, duration and intensity at the 39 meteorological stations in Iraq during the past 30 years. The SPI computed at various time scales was used as an indicator of drought severity. The SPI analysis indicated that the years 1983,1998,1999,2000 and 2008 were the year's most affected by drought during the investigation period, the northeast region of Iraq during the driest year 1999 faced high drought. The relationships between drought duration and magnitude are provided in the form of scatter diagrams with the best straight line fits. The drought magnitude can be obtained corresponding to a given drought duration from the magnitude-duration graphs, which gives an idea about the water need in a critical period in a watershed for different purposes.

\section{Acknowledgement}

We would like to thank to everyone working on the Iraq Virtual Science Library (IVSL).

\section{References}

[1] D. A.Wilhite, and M. H.Glantz, Water International, 10 (1985) 111.

[2] A. K. Mishra, and V. P. Singh, Journal of Hydrology, 391 (2010) 202.

[3] T.Tadesse, , D.Wilhite, , S.Harms, , M. Hayes, and S.Goddard, Journal of Natural Hazards, 33, 1 (2004) 137.

[4]S.Sirdas, and Z. Sen, Journal of Hydrological Science, 48,5 (2203) 809.

[5]T. B. McKee, N.J. Doesken and N. Kleist, Preprints, 8th Conference on Applied Meteorology, Anaheim, CA (1993) 179184.

[6] T. B.McKee, N. J. Doesken and Kleist, Ninth Conf. on Applied Climatology (Dallas, Texas), (1995) 233-236.

[7] K.Yaseen and H. Monim, Journal of Energy and Environment, 4, 2 (2013) 292.

[8] D.C.Edwards, and T.B. Mckee, Climatology Report 79, 2 (1997). 